\title{
CUTANEOUS SPOROTRICHOSIS TREATMENT WITH POTASSIUM IODIDE. A 24 YEAR EXPERIENCE IN SÃO PAULO STATE, BRAZIL
}

Karin YAMADA(1), Clarisse ZAITZ(2), Valéria Maria de Souza FRAMIL(3) \& Laura Hitomi MURAMATU(4)

\begin{abstract}
SUMMARY
Background: Sporotrichosis is a subacute or chronic disease caused by a dimorphic fungus, Sporothrix schenckii. The first and most traditional treatment is potassium iodide in satured solution (SSKI) used by DE BEURMANN in 1907. For its effectiveness, it is still used for cutaneous sporotrichosis. Objective: To evaluate the treatment of cutaneous sporotrichosis with SSKI in relation to clinical cure, side effects, length of treatment and reactivation. Methods: We conducted a retrospective analysis of medical records over a 24-year period (1981-2005). Patients of all ages who were treated in the hospital's division of dermatology were included in the study providing that they had a positive culture of S. schenckii. Satured solution of potassium iodide ( 3 to $6 \mathrm{~g}$ per day) was the treatment prescribed. For children, half of the dose was prescribed. Results: The lymphocutaneous disease was prevalent, the cure rate was $94.7 \%$, side effects were described in $5.5 \%$ of the cases, mean length of treatment was 3.5 months and possible reactivation was observed in $11.1 \%$. Conclusion: SSKI is an effective drug, with many side effects, but with low frequency. Resolution was for maximum six months of treatment. SSKI has been found to be a very effective drug in this retrospective study of culture-proven cases of cutaneous and lymphocutaneous sporotrichosis. It should be used as first drug of choice especially in resource-limited settings.
\end{abstract}

KEYWORDS: Sporotrichosis; Mycosis; Sporothrix schenckii; Potassium iodide.

\section{INTRODUCTION}

Sporotrichosis is a subacute or chronic disease of human beings and animals caused by the dimorphic fungus Sporothrix schenckii. The infection is usually localized in the skin and subcutaneous tissue. Systemic disease is rare and it may be developed by inhalation of spores through the respiratory tract ${ }^{2}$.

It occurs worldwide, but it is endemic in South Africa ${ }^{19}$, Central America, South America ${ }^{6,18,23}$, Japan and India ${ }^{21}$, more commonly seen in tropical and subtropical zone regions ${ }^{24}$.

Since 1998 we have been observing an increasing number of cases of sporotrichosis in Rio de Janeiro, Brazil and surrounding areas. Most cases were from underprivileged areas on the outskirts of the city, and mostly originated from feline sporotrichosis ${ }^{1}$.

Zoonotic transmission has been reported in isolated cases. Many animals are considered susceptible such as horses, dogs, cats, rats, pigs, cows and armadillos ${ }^{20}$. Sporotrichosis affects people of any age, either male or female without any predisposing factor, except in the systemic form. It is associated with agricultural, gardening and other activities that promote traumatic contact with plant material or soil ${ }^{15}$.

Sporotrichosis is classified in cutaneous forms (lymphocutaneous and fixed cutaneous), extracutaneous and disseminated forms. The lymphocutaneous form is the most common ${ }^{2}$.

For a definitive diagnosis of this mycosis, fungal culture should be performed ${ }^{22,24}$. Colonies performed at room temperature present a creamy white color that convert into the characteristic brown-black leathery colonies. At $37^{\circ} \mathrm{C}$, the colony turns to a yeast-form and a creamy aspect with irregular surface ${ }^{13}$.

The demonstration of the long, thin, hyaline hyphae and conidia displaying a bouquet configuration, like daisies on the microscope associated with the fungus dimorphism confirms the diagnosis ${ }^{28}$.

Treatment of sporotrichosis can be difficult, mainly due to patient compliance over long duration treatment. In addition, it is expensive, especially with use of the new antifungal drugs ${ }^{9}$.

Cutaneous and lymphocutaneous sporotrichosis should be treated with itraconazole or SSKI (satured solution of potassium iodide) in countries in which the latter is the standard of care ${ }^{11}$. It was first used by DE BEURMANN in 1907 and is still one of the most prescribed for its effectiveness and low $\operatorname{cost}^{7,22}$.

The disadvantages of potassium iodide are the length of the

(1) Pós-graduanda da Faculdade de Ciências Médicas da Santa Casa de São Paulo, São Paulo, SP, Brasil.

(2) Professora adjunta da Faculdade de Ciências Médicas da Santa Casa de São Paulo, São Paulo, SP, Brasil.

(3) Professora segundo assistente da Faculdade de Ciências Médicas da Santa Casa de São Paulo, São Paulo, SP, Brasil.

(4) Biómédica do laboratório de Micologia da Clínica de Dermatologia da Santa Casa de São Paulo, São Paulo, SP, Brasil.

Sources of Funding: CAPES

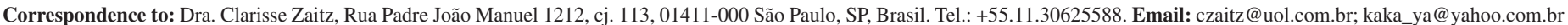


YAMADA, K.; ZAITZ, C.; FRAMIL, V.M.S. \& MURAMATU, L.H. - Cutaneous sporotrichosis treatment with potassium iodide. A 24-year experience in São Paulo State, Brazil. Rev. Inst. Med. Trop. Sao Paulo, 53(2): 89-93, 2011.

treatment, relapses if not taken after clinical cure for at least two weeks and the limited effectiveness in the systemic form ${ }^{7}$. Besides that, SSKI is inconvenient to take because of its taste and many side effects ${ }^{3}$. Some cases showing association of SSKI with itraconanazole ${ }^{8,12}$ and terbinafine ${ }^{17}$ were described.

The objective of our study was to describe the treatment of cutaneous sporotrichosis with SSKI in relation to clinical cure, side effects, length of treatment and relapse.

\section{MATERIAL AND METHODS}

Patients were identified through a retrospective review of fungal tests performed at the laboratory of mycology of the division of dermatology of the hospital Santa Casa de São Paulo during a 24-year-period (January 1, 1981 - December 31, 2005). The study was approved by the Ethics and Research Committee of the "Irmandade da Santa Casa de São Paulo".

Patients of all ages who were treated in the hospital's division of dermatology were included in the study provided that they had a positive culture of $S$. schenckii, obtained through a specimen of a draining skin lesion (scraping) or needle biopsy of a nonexudative lesion. The direct microscopic examination using potassium hydroxide was used in all patients. The patients who did not follow-up or presented a form other than the cutaneous and lymphocutaneous sporotrichosis were excluded from this study.

Samples obtained from skin lesions for isolation of S. schenckii were inoculated on Agar Mycobiotic (Difco) for three to five days, incubated at $25{ }^{\circ} \mathrm{C}$, and submitted to macroscopic and microscopic examination.

On identification of a case of sporotrichosis, we reviewed the corresponding medical records (if available) and recorded the data on a standardized form. Side effects were considered when signs and symptoms were described in the records. There was a protocol where the dosage of SSKI and the side effects could be written.

The treatment for all patients was SSKI (3-6g/day for adults and half of the dose for children maintained for two weeks after total regression of the lesions). Patients considered cured were the ones whose followup was done every three months after clinical cure (total healing of the lesion) for one year. Patients with reinfection or incomplete treatment were those who had clinical cure initially, but during follow up showed sporotrichosis lesions. We considered treatment incomplete when the medication was suspended before the total healing of the lesion or when it was not maintained for two weeks after the regression of the lesion.

The data collected from each patient were analyzed using software (Epi-Info). Statistical methods used for this analysis included frequency, mean, SD, percentage, median, minimum, maximum, Chi-square test and Fisher's exact test. A value of $p<0.05$ was considered significant.

\section{RESULTS}

Among the 51 cases of sporotrichosis identified, some data information were not identified in the 26 records available in the hospital. Among these 26 records, only 18 completed the whole treatment and were followed-up for a one-year-period. One patient had the systemic form and was also excluded.
There was a male preponderance among the 18 patients. Males were $72.2 \%$ and females were $27.8 \%$. Most cases were diagnosed in the 1980's and 1990's.

Mean age was 34.7 years and median 34 years. Age ranged from one to 73 years. $27.8 \%$ were under 18 years.

Occupations most common were those that had activities involving trauma and exposure to contaminated soil or vegetation such as gardening, farming and carpentry $(66.7 \%)$, followed by students $(25 \%)$ and other professions $(8.3 \%)$.

The direct microscopic examination was negative in $100 \%$.

The most frequent form of cutaneous sporotrichosis was the lymphocutaneous form $(66.7 \%)$ followed by the fixed cutaneous form $(33.3 \%)$.

Among the 18 cases that finished the entire treatment, the shortest period of treatment was one month, mean was 3.5 months and maximum was six months. $61.1 \%$ of the patients were treated for a maximum of three months.

There was a major deficiency in data of the side effects that has not been available in the records. There were no side effects described in the patient's records in $94.5 \%$. The only patient who presented side effects was a 14-year-old female with fixed cutaneous form. She was taking $3 \mathrm{~g} /$ day of SSKI. Diarrhea, nausea and headache were described in the records. Medication was suspended for a week and then the dose was decreased to $2 \mathrm{~g} /$ day for five months. With this dose, there was not complaint.

All patients responded to SSKI treatment initially. Two patients $(11.1 \%)$ had new lesions after SSKI short treatment. The first case was a one-year-old female with the fixed cutaneous form on the face. Seven months after she finished a one-month-period treatment, the mother noticed a lesion on the face once again. SSKI was prescribed for another two months and she was cured.

The second case was a 36-year-old male with the fixed cutaneous form in the leg after trauma. The length of the treatment was two months. Two years after the end of the treatment, new lesions appeared. He was treated with SSKI for three more months and was also cured.

When analyzing the length of treatment and the form of the disease, we noticed that nine patients had fixed cutaneous form with a mean treatment of three months. The minimum was one month, median was three months and maximum was five months.

Eight patients with lymphocutaneous lesions were treated for a maximum three months and four patients for more than four months. $50 \%$ of the patients with localized form were treated for maximum three months.

The distribution of patients according to length of treatment and the variables (sex, age and reinfection) is in Table 1. For this analysis, the length of the treatment was divided into two groups (up to three months and more than four months). There was no significant statistical association. 


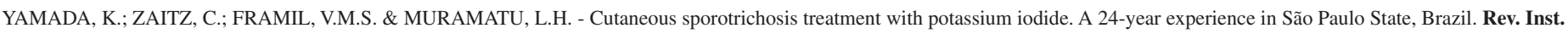
Med. Trop. Sao Paulo, 53(2): 89-93, 2011.

Table 1

Distribution according to length of treatment, sex, age and reinfection in 26 patients with sporotrichosis

\begin{tabular}{|c|c|c|c|c|}
\hline & & Treatment $\leq 3$ months & Treatment $\geq 4$ months & Total \\
\hline \multirow[t]{2}{*}{ Sex } & Male & $9(69.2 \%)$ & $4(30.8 \%)$ & $13(100 \%)$ \\
\hline & Female & $2(40 \%)$ & $3(60 \%)$ & $5(100 \%)$ \\
\hline \multirow[t]{3}{*}{ Age } & $1-18 y$ & $3(60 \%)$ & $2(40 \%)$ & $5(100 \%)$ \\
\hline & $19-60 y$ & $6(60 \%)$ & $4(40 \%)$ & $10(100 \%)$ \\
\hline & $>60 y$ & $2(66.7 \%)$ & $1(33.3 \%)$ & $3(100 \%)$ \\
\hline \multirow[t]{2}{*}{ Reinfection/Relapse } & Yes & $2(100 \%)$ & 0 & $2(100 \%)$ \\
\hline & No & $9(56.2 \%)$ & $7(43.8 \%)$ & $16(100 \%)$ \\
\hline
\end{tabular}

$\mathrm{y}$ - years old.

\section{DISCUSSION}

This is a case series of cutaneous and lymphocutaeous sporotrichosis, a retrospective review. Treatment with SSKI has been found to be effective.

In our study we observed that more cases were treated in the 80 's when compared to more recent years. This may have occurred because of the urbanization and more know-how of clinicians to diagnose and treat the disease.

Ecological factors that have been associated with its development are temperatures between $26^{\circ} \mathrm{C}$ and $27^{\circ} \mathrm{C}$ and presence of organic material. For this reason, sporotrichosis is considered to be acquired during outdoor leisure or occupational activities that promote frequent and traumatic contact with plant material or soil ${ }^{5}$. In agreement with these observations, we found that $66.7 \%$ of patients had an occupational hazard.

The sex distributions of the disease vary from region to region depending on conditions of exposure ${ }^{21}$. In our study, most patients were male $(72.2 \%)$, and that is described in many other studies ${ }^{4,5,15}$. Some authors, on the other hand, find no prevalence of either male of female $e^{7,8}$. Higher prevalence in females has been reported among Indian women working in agriculture ${ }^{21}$ and in a zoonotic epidemic in Rio de Janeiro, probably from continuous contact with infected cats ${ }^{25}$.

In relation to age, we observed that most patients were adults. Adults represent the highest proportion of cases in most endemic areas, but it may vary also from area and population. National studies describe that the mean age is higher each decade. Between 1960 and 1970, children and young adults were the most affected ${ }^{4,15}$. In the study published by MARQUES et al. $(1997)^{19}$, the higher prevalence was in older patients. The median age in Rio de Janeiro was 39 years ${ }^{25}$. In Japan, most of the patients were children and adults above 50 years $^{27}$.

Direct microscopic examination of the specimen is often of little or no value in sporotrichosis. In our study, it was negative in $100 \%$. On the other hand, the fungal culture, considered the gold standard exam for diagnosis, was used in our study.

The commonest presentation of the disease was the lymphocutaneous form $(66.7 \%)$, followed by the fixed cutaneous form $(33.3 \%)$ similar to studies. On the contrary, in Australia ${ }^{4}, \mathrm{Japan}^{27}$ and the State of Rio Grande do Sul, Brazil ${ }^{14}$, this prevalence was not noticed.

Although itraconazole turns out to be the treatment of choice for the cutaneous forms of sporotrichosis, it is still an expensive treatment (15 capsules of Itraconazole costs US\$ 30.00 in Brazil). Potassium iodide, therefore, is commonly prescribed in developing countries.

Potassium iodide is usually administered in the form of a saturated solution (SSKI) at a dose of $47 \mathrm{mg} /$ drop. After ingestion, potassium iodide is readily absorbed in the intestinal tract and distributed rapidly through the extracellular space. It concentrates in the thyroid gland, salivary glands, gastric mucosa, choroid plexus, mammary glands, and the placenta. Ninety percent of the orally administered dose is excreted in the urine. Sweat, breast milk, and feces account for the remainder of the excretion ${ }^{26}$.

The initial dose for adults is five drops three times a day, increasing one drop per dose per day ${ }^{7}$. Usually the dose varies from two to three grams per day ${ }^{13}$ and it may reach six grams per day ${ }^{16}$. Administration with fruit juices or milk may mitigate against gastrointestinal side effects. It is recommended that the therapeutic dose should be maintained for up to four weeks beyond the time of total clinical cure ${ }^{22,24}$.

Children with cutaneous and lymphocutaneous sporotrichosis should be treated with itraconazole. Dosages of either $100 \mathrm{mg}$ daily or 6-10 mg/ $\mathrm{kg}$ daily (to a maximum of $400 \mathrm{mg}$ daily) have been used. SSKI has also been used as treatment for dosages of one drop administered three times daily, up to a maximum of one drop/kg or 40-50 drops administered three times daily ${ }^{11}$. RAMOS-E-SILVA et al. $(2007)^{24}$ recommended maximum dose of 25 drops three times daily.

In the present study all patients were exclusively treated with SSKI and initially it was successful in all 18 patients, with total healing of the cutaneous lesions. Among them, the mean duration was 3.5 months. In $61.1 \%$ of the patients were treated for maximum three months. The two patients that had new lesions after treatment with SSKI, received a short period of treatment, but after taking another regular SSKI therapy there was no recurrence in any of them. Some papers say that sporotrichosis immunity is not prolonged. SSKI should always be continued for another two weeks after the clinical cure to reduce relapse.

MARQUES et al. (1997) ${ }^{19}$ described cure with SSKI in two months in most of the patients. In the study realized by DA ROSA et al. $(2005)^{5}$, 
YAMADA, K.; ZAITZ, C.; FRAMIL, V.M.S. \& MURAMATU, L.H. - Cutaneous sporotrichosis treatment with potassium iodide. A 24-year experience in São Paulo State, Brazil. Rev. Inst. Med. Trop. Sao Paulo, 53(2): 89-93, 2011.

all 304 patients were cured in up to 16 weeks. Even in the United States, a country with higher income, one patient was treated successfully with SSKI for eight weeks 9 .

Potassium iodide has significant side effects even though not found in our study. Usually, these reactions are not severe and the drug may be suspended or prescribed in lower doses ${ }^{7}$. It has also been reported to cause less common, but severe side effects, such as pulmonary edema, angioedema, lymphadenopathy, vasculitis, periarteritis nodosa, pustular psoriasis, metabolic acidosis, cardiac irritability and bullous pemphigoid ${ }^{26}$.

Prolonged usage leads to the interruption of the endogenous production of thyroid hormones, a phenomenon known as the WolfChaikoff effect ${ }^{6,24}$. It may also cause Jod-Basedow phenomenon because of absent autoregulation, thyreoiditis ${ }^{10}$, hypo or hyperthireoidism ${ }^{26}$. After suspension of the drug for one month, hormones usually normalize ${ }^{6}$. If therapy with potassium iodide continues for more than one month, however, a screening TSH is prudent to ensure that iodide-induced hypothyroidism does not ensue ${ }^{10}$.

Patients with renal function impairment or those taking angiotensinconverting enzyme inhibitors or potassium-sparing diuretics are at increased risk for potassium toxicity ${ }^{26}$.

HABTE-GABR \& WALSH $(2001)^{9}$ presented one case treated with SSKI at a dose of $4 \mathrm{~mL}$ three times daily for eight weeks. There was a complete remission of the lymphocutaneous sporotrichosis and the only side effect was a bitter taste.

Although many side effects were described such as gastrointestinal disturbance, coryza, rash, salivary enlargement and metallic taste, in a few cases the drug dose was lowered or suspended in this study. Although there was a major deficiency in data that has not been available, of the 18 cured cases, there were no signs or symptoms related to SSKI described in patients files in $94.5 \%$, which is similar to the literature. There was only one patient relating diarrhea and headache while on SSKI therapy. After reducing the dosage, there were no complaints.

Most cases described in literature suspended SSKI because of intolerance and not reinfection. KOÇ et al. in $1999^{12}$ presented a lymphocutaneous case treated with SSKI and itraconazole. Clinical cure was observed after two months.

There was no statistic significance among sex, age and length of treatment. In males and all ages, the length of treatment up to three months was prevalent. So, even the older patients, who may have associated conditions, responded rapidly with SSKI.

\section{CONCLUSION}

In the present study we conclude that with our 24-year experimence, the treatment of sporotrichosis with SSKI is effective, with total healing of the lesions in all patients. It has many side effects as described, but with low frequency. Resolution of the disease was noticed in maximum six months of treatment. Reinfection is possible, especially when treatment is for a short period. We recommend SSKI be used as first choice in resource-limited settings for cutaneous, lymphocutaneous sporotrichosis.

\section{AUTHOR'S CONTRIBUTION AND CONFLICT OF INTEREST}

This is an original Paper. The manuscript and all parts of it have not been submitted elsewhere. The manuscript has been read by all authors carefully. All authors agree that the manuscript represents their work.

There are no financial or other relationships from any of the authors of the manuscript that might lead to any conflict of interest.

\section{RESUMO}

\section{Tratamento da esporotricose cutânea com SSKI. Experiência de 24 anos no Estado de São Paulo, Brasil.}

Fundamentos: Esporotricose é doença subaguda ou crônica causada pelo fungo dimórfico Sporothrix schenckii. O primeiro e mais tradicional tratamento é o iodeto de potássio em solução saturada (SSKI) usado por De Beurmann em 1907. Por ser eficaz,ainda é muito utilizada no nosso meio para o tratamento da esporotricose cutânea. Objetivos: Avaliar o tratamento da esporotricose cutânea com SSKI em relação à cura clínica, efeitos colaterais, tempo de tratamento e recidiva. Métodos: A partir da revisão dos resultados de exames do laboratório de Micologia da Clínica de Dermatologia da Santa Casa de SP, durante 1981 a 2005, foram incluídos pacientes de qualquer idade com lesão cutânea sugestiva de esporotricose e cultura positiva para S. schenckii. Em todos pacientes o tratamento prescrito foi SSKI na dose de 3 a $6 \mathrm{~g} /$ dia para adultos, por um período de até duas semanas após cura clínica. Em crianças foi utilizada a metade da dose. Resultados: Houve predomínio da forma cutânea localizada, taxa de cura de $94,7 \%$, efeitos colaterais em 5,5\%, média de tempo de tratamento de 3,5 meses e $11,1 \%$ de provável recidiva. Conclusão: A SSKI é eficaz, com diversos efeitos colaterais, porém de baixa frequência, permanecendo indicada para as formas cutâneas da esporotricose.

\section{ACKNOWLEDGMENTS}

This work was supported by CAPES. The authors would like to thank Ting Hui Ching and Daniel Kashiwamura Scheffer, from the Biostatistics Department of the Faculdade de Ciências Médicas da Santa Casa de São Paulo.

\section{REFERENCES}

1. Barros MBL, Schubach TMP, Gutierrez Galhardo MC, Schubach AO, Monteiro PCF, Reis RS, et al. Sporotrichosis: an emergent zoonosis in Rio de Janeiro. Mem Inst Oswaldo Cruz. 2001;96:777-9.

2. Campbell I. Esporotricose. In: Zaitz C, Campbell I, Marques SA, Ruiz LRB, Souza VM. Compêndio de micologia médica. Rio de Janeiro: MEDSI; 1998. p. 123-137.

3. Chapman SW, Pappas P, Kauffmann C, Smith EB, Dietze R, Tiraboschi-Foss N, et al. Comparative evaluation of the efficacy and safety of two doses of terbinafine (500 and $\left.1000 \mathrm{mg} \mathrm{day}^{-1}\right)$ in the treatment of cutaneous or lymphocutaneous sporotrichosis. Mycoses. 2004;47(1-2): 62-8.

4. Conias S, Wilson P. Epidemic cutaneous sporotrichosis: report of 16 cases in Queensland due to mouldy hay. Australas J Dermatol. 1998;39:34-7.

5. Da Rosa ACM, Scroferneker ML, Vettorato R, Gervini RL, Vettorato G, Weber A. Epidemiology of sporotrichosis: a study of 304 cases in Brazil. J Am Acad Dermatol. 2005;52(3 Pt 1):451-9. 


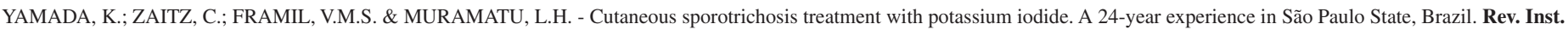
Med. Trop. Sao Paulo, 53(2): 89-93, 2011.

6. De Araujo T, Marques AC, Kerdel F. Sporotrichosis. Int J Dermatol. 2001;40:737-42.

7. Donadel KW, Reinoso YD, de Oliveira JC, Azulay RD. Esporotricose: revisão. An Bras Dermatol. 1993;68:45-52.

8. Gurcan S, Konuk E, Kilic H, Otkun M, Ener B. Sporotrichosis, a disease rarely reported from Turkey, and an overview of Turkish literature. Mycoses. 2007;50:426-9.

9. Habte-Gabr E, Walsh W. Cutaneous sporotrichosis: the old iodide treatment remain effective. Clin Microbiol Infect. 2000;6:55

10. Heymann WR. Potassium iodide and the Wolff-Chaikoff effect: relevance for the dermatologist. J Am Acad Dermatol. 2000;42:490-2.

11. Kauffman CA, Bustamante B, Chapman SW, Pappas PG. Clinical practice guidelines for the management of sporotrichosis: 2007 update by the Infectious Diseases Society of America. Clin Infect Dis. 2007;45:1255-65.

12. Koç AN, Uksal U, Oymak O. Case report. Successfully treated subcutaneous infection with Sporothrix schenckii in Turkey. Mycoses. 2001;44:330-3.

13. Lacaz CS, Porto E, Martins JEC, Heins-Vaccari EM, Melo NT. Esporotricose e outras micoses gomosas. In: Lacaz CS, Porto E, Martins JEC, Heins-Vaccari EM, Melo NT, editors. Tratado de micologia médica. 9ªed. São Paulo: Sarvier; 2002. p. 479-497.

14. Londero AT, Ramos CD. Esporotricose no Rio Grande do Sul: três decadas de observação. An Bras Dermatol. 1989;64:307-10.

15. Lopes JO, Alves SH, Mari CR, Brum LM, Westphalen JB, Altermann MJ, et al. Epidemiologia da esporotricose na regiäo central do Rio Grande do Sul. Rev Soc Bras Med Trop. 1999;32:541-5

16. Lopes-Bezerra LM, Schubach A, Costa RO. Sporothrix schenckii and sporotrichosis. An Acad Bras Cienc. 2006;78:293-308.

17. Lorenz AM, de los Ríos E, de los Ríos R, Cartagena N. Esporotricosis linfangítica. Dermatol. Argent. 2003;9:192-3.
18. Lyon GM, Zurita S, Casquero J, Holgado W, Guevara J, Brandt ME, et al. Population-based surveillance and a case-control study of risk factors for endemic lymphocutaneous sporotrichosis in Peru. Clin Infect Dis. 2003;36:34-9.

19. Marques SA, Sueto M, Camargo RMP, Lastória JC, Fagundes LK, Dillon NL. Sporotrichosis: survey and clinical aspects from Botucatu School of Medicine, state of Säo Paulo - Brazil. An Bras Dermatol. 1997;72:343-7.

20. Marques SA, Franco SRVS, Camargo RMP, Dias LDF, Haddad Júnior V, Fabris VE. Esporotricose do gato doméstico (Felis catus): transmissão humana. Rev Inst Med Trop Sao Paulo. 1993;35:327-30.

21. Mohan N, Jayaseelan E, Abraham A, Rajendran SC, Stephen J, Sharief S, et al. Cutaneous sporotrichosis in Bangalore, southern India. Int J Dermatol. 2004;43:269-72.

22. Morris-Jones R. Sporotrichosis. Clin Exp Dermatol. 2002;27:427-31

23. Pappas PG, Tellez I, Deep AE, Nolasco D, Holgado W, Bustamante B. Sporotrichosis in Peru: description of an area of hyperendemicity. Clin Infect Dis. 2000;30:65-70.

24. Ramos-e-Silva M, Vasconcelos C, Carneiro S, Cestari T. Sporotrichosis. Clin Dermatol. 2007;25:181-7.

25. Schubach A, Barros MBL, Wanke B. Epidemic sporotrichosis. Curr Opin Infect Dis 2008;21:129-33

26. Sterling JB, Heymann WR. Potassium iodide in dermatology: a $19^{\text {th }}$ century drug for the $21^{\text {st }}$ century-uses, pharmacology, adverse effects, and contraindications. J Am Acad Dermatol. 2000;43:691-7.

27. Tanuma H, Asai T, Abe M, Nishiyama S, Katsuoka K. Case report. Lymphatic vessel-type sporotrichosis: immunohistochemical evaluation and cytokine expression pattern. Mycoses. 2001;44:316-20.

28. Zaitz C, Ruiz LRB, de Souza VM. Identificação dos fungos. In: Zaitz C, Ruiz LRB, de Souza VM. Atlas de micologia. Rio de Janeiro: MEDSI; 2004. p. 29

Received: 22 September 2009

Accepted: 16 February 2011 


\section{LIBRARY OF THE SÃO PAULO INSTITUTE OF TROPICAL MEDICINE}

Website: www.imt.usp.br/portal

Address: Biblioteca do Instituto de Medicina Tropical de São Paulo da Universidade de São Paulo Av. Dr. Enéas de Carvalho Aguiar, 470. Prédio 1 - Andar térreo.

05403-000 São Paulo, SP, Brazil.

Telephone: 5511 3061-7003 - Fax: 5511 3062-2174

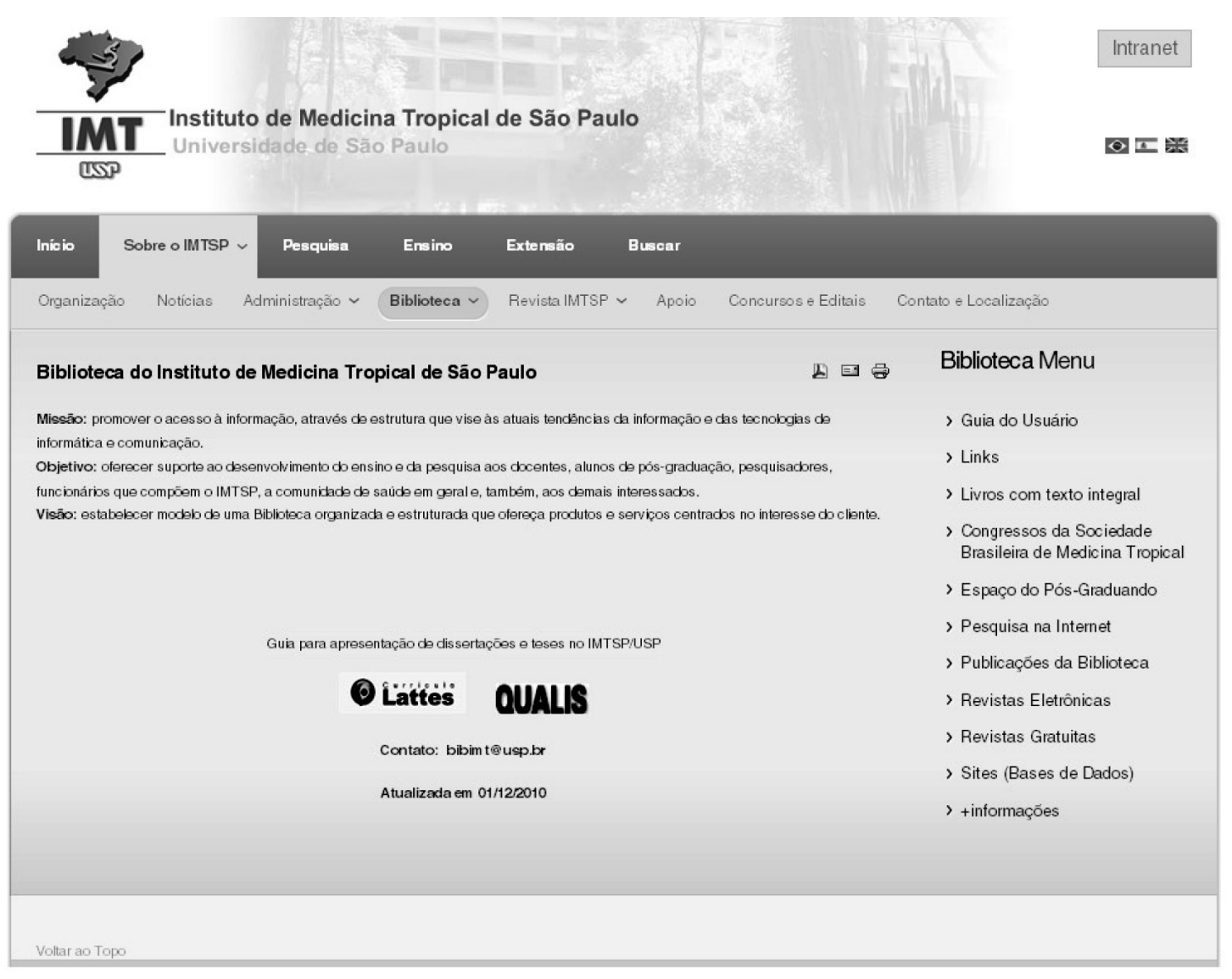

The Library of the São Paulo Institute of Tropical Medicine (IMTSP Library) was created on January 15,1959 in order to serve all those who are interested in tropical diseases. To reach this objective, we select and acquire by donation and / or exchange appropriate material to be used by researchers and we maintain interchange between Institutions thorough the Journal of the São Paulo Institute of Tropical Medicine, since the Library has no funds to build its own patrimony.

The IMTSP Library has a patrimony consisting of books, theses, annals of congresses, journals, and reference works.

The collection fo journals existing in the Library can be verified through the USP - Bibliographic Database - OPAC - DEDALUS http://dedalus.usp.br:4500/ALEPH/eng/USP/USP/DEDALUS/start of the USP network. 